( 2022 , The Authors. Published by Elsevier Inc. and Fass Inc. on behalf of the American Dairy Science Association ${ }^{\circledR}$. This is an open access article under the CC BY license (http://creativecommons.org/licenses/by/4.0/).

\title{
Abomasal infusion of different exogenous emulsifiers alters fatty acid digestibility and milk fat yield of lactating dairy cows
}

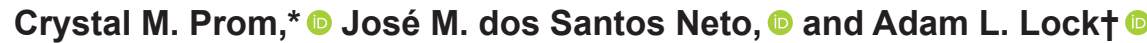 \\ Department of Animal Science, Michigan State University, East Lansing 48824
}

\begin{abstract}
We evaluated the effects of abomasal infusion of emulsifiers on fatty acid (FA) digestibility and milk production of lactating dairy cows. All emulsifiers examined were polysorbates, nonionic surfactants, consisting of a polyethoxylated sorbitan esterified with FA. The polysorbates tested in this study consisted of the same polyethoxylated sorbitan base but differed by the FA esterified to it. Eight rumen-cannulated multiparous cows $(89 \pm 13 \mathrm{~d}$ in milk) were assigned to a treatment sequence in $4 \times 4$ Latin squares with 18-d periods consisting of $7 \mathrm{~d}$ of washout and $11 \mathrm{~d}$ of infusion. Treatments were abomasal infusions of water only $(\mathrm{CON})$ or $30 \mathrm{~g} / \mathrm{d}$ of different emulsifiers as follows: polysorbate-C16:0 (T40), polysorbate-C18:0+C16:0 (T60), and polysorbate-C18:1 (T80). Emulsifiers were dissolved in water and delivered at 6-h intervals (total daily infusion was divided into 4 equal infusions per day). Cows were fed the same diet that contained (\% diet dry matter) $32.1 \%$ neutral detergent fiber, $15.7 \%$ crude protein, $25.8 \%$ starch, and $3.32 \%$ FA (including $1.92 \%$ FA from a saturated FA supplement containing $34.2 \% \mathrm{C} 16: 0$ and $47.7 \% \mathrm{C} 18: 0)$. The $\mathrm{T} 80$ treatment increased total FA digestibility compared with CON (5.40 percentage units) and T60 (3.90 percentage units) and tended to increase it compared with T40. Also, T40 tended to increase and T80 increased (4.80 percentage units) 16-carbon FA digestibility compared with CON. The T80 treatment increased 18-carbon FA digestibility compared with the other treatments. The T40 treatment tended to increase and T80 increased total FA absorption compared with CON $(53 \mathrm{~g} / \mathrm{d})$ and T60 $(52 \mathrm{~g} / \mathrm{d})$. Both T40 and T80 increased the absorption of 16-carbon FA compared with CON and T60. The T60 treatment did not differ from CON for any

Received September 20, 2021

Accepted December 6, 2021.

*Current address: Cargill Inc., 15407 McGinty Rd W, Wayzata, MN 55391.

†Corresponding author: allock@msu.edu
\end{abstract}

digestibility variable. Both T40 and T80 increased the yields of milk fat, $3.5 \%$ fat-corrected milk, and de novo, mixed, and preformed milk FA compared with CON. In conclusion, not all emulsifiers increased FA digestibility. Compared with CON, T80 increased the digestibility and absorption of total, 16-, and 18-carbon FA. The T40 treatment tended to increase and T80 increased total FA absorption and the yields of milk fat and 3.5\% FCM compared with CON. Milk fat yield was increased by increases in de novo, mixed, and preformed milk FA. In our short-term infusion study, results suggest that the predominant FA present in the polysorbate affects its ability to improve FA digestibility. Overall, FA digestibility and absorption were improved the most when cows received the T80 treatment.

Key words: emulsifier, fatty acid digestibility, milk fat

\section{INTRODUCTION}

It is established that increasing the amount of fatty acids (FA) reaching the duodenum can have a negative effect on FA digestibility (Boerman et al., 2015). Both bile salts and lysolecithin, a natural emulsifier produced from lecithin in the small intestine, play critical roles in micelle formation and absorption of FA in ruminant animals (Carey et al., 1983). Although bile salts are efficiently recycled, the amount of lysolecithin produced by the cow may be a limiting factor to FA absorption, especially as the flow of FA to the small intestine increases (Drackley, 2000; Maldonado-Valderrama et al., 2011). We recently reported the potential for an exogenous emulsifier to improve FA absorption (de Souza et al., 2020). As such, continued investigation of supplemental exogenous emulsifiers may be an important strategy to improve FA absorption and increase total digestible energy for dairy cows.

Surfactants are a class of emulsifiers with amphiphilic properties that disrupt surface tension and promote the formation and stabilization of an emulsion (Kralova and Sjöblom, 2009). This then allows 2 immiscible liquids, such as oil and water, to be thoroughly combined. Many surfactants will self-aggregate to form micelles with the polar head groups facing outwards and the 
nonpolar hydrophobic tails facing inwards (Carey and Small, 1970). Nonpolar substances, such as C16:0 and C18:0, can then be contained within the micelle and suspended in aqueous environments. As such, micelles are critical for the transport of FA from feed particles in the lumen of the small intestine through the unstirred water layer to be absorbed by enterocytes (Noble, 1987; Doreau and Ferlay, 1994).

Polysorbates are nonionic surfactants consisting of a polyethoxylated sorbitan esterified with FA. They are commonly used in the pharmaceutical (Kaur and Mehta, 2017) and food (Kralova and Sjöblom, 2009) industries to stabilize emulsions but have not been extensively studied in ruminant nutrition. Some studies have examined the effects of polysorbate on ruminal fermentation of fiber, both in vitro and in vivo (Kamande et al., 2000; Ahn et al., 2009; Cong et al., 2009), as a means to emulsify lipophilic treatments into solution to be abomasally or intravenously infused (Erickson et al., 1963; Drackley et al., 2007), or included in milk replacer (Jenkins and Emmons, 1984). However, to our knowledge, only one study has investigated the use of polysorbate as an emulsifier to improve FA digestibility (de Souza et al., 2020). We observed that abomasal infusion of $30 \mathrm{~g} / \mathrm{d}$ of a polysorbate increased FA digestibility from 61 to $71 \%$. However, it is important to note that polysorbates can be esterified with different FA, such as C16:0, C18:0, and cis-9 C18:1. We are not aware of previous research that has compared polysorbates esterified with different FA. This is important considering that supplemental FA blends containing cis-9 C18:1 typically have the highest total FA digestibility, followed by C16:0, then by C18:0 (de Souza et al., 2019; Western et al., 2020a; Prom and Lock, 2021), and we recently reported that abomasally infusing cis$9 \mathrm{C} 18: 1$ from 0 to $60 \mathrm{~g} / \mathrm{d}$ linearly increased total FA digestibility (Prom et al., 2021). Thus, differences in the FA content of various polysorbates may affect their ability to alter FA digestibility in the small intestine.

Therefore, the objective of our study was to compare the effect of different exogenous emulsifiers on their ability to improve FA digestibility. We hypothesized that all polysorbates would increase FA digestibility. We further hypothesized that the increase in FA digestibility will be greatest for the polysorbate containing the most cis-9 C18:1.

\section{MATERIALS AND METHODS}

\section{Design and Treatments}

All experimental procedures were approved by the Institutional Animal Care and Use Committee at Michigan State University (East Lansing, MI). Eight ruminally cannulated multiparous Holstein cows averaging (mean $\pm \mathrm{SD}$ ) $89 \pm 13 \mathrm{DIM}, 46.8 \pm 4.7 \mathrm{~kg}$ of milk, and $625 \pm 39 \mathrm{~kg}$ of $\mathrm{BW}$ were randomly assigned to treatment sequences in a replicated $4 \times 4$ Latin square design. Cows were blocked by milk yield and balanced for parity and BCS. Each 18-d treatment period consisted of a 7-d washout period and an 11-d infusion period, with sampling during the last $4 \mathrm{~d}$ (de Souza et al., 2020; Prom et al., 2021). Treatments were abomasal infusions of water carrier only $(\mathbf{C O N})$ or $30 \mathrm{~g} / \mathrm{d}$ of emulsifiers enriched in different FA as follows: polysorbate-C16:0 (T40), polysorbate-C18:0+C16:0 (T60), and polysorbate-C18:1 (T80; Tween, Sigma-Aldrich). The FA composition of the polysorbates is shown in Table 1. Daily doses of emulsifiers were suspended in $200 \mathrm{~mL}$ of water in individual glass jars. The acronyms T40, T60, and T80 are used only when referring to the abomasal infusion treatments of polysorbates in the current study. The dose was chosen based on results from our dose response study using polysorbate-C18:1 (de Souza et al., 2020). The total infusate solution was divided into 4 infusions per day occurring every $6 \mathrm{~h}$ based on our previous studies (Lock et al., 2007; de Souza et al., 2020; Prom et al., 2021). Stainless steel abomasal infusion devices as described by WestreicherKristen and Susenbeth (2017), with the addition of a circular, flexible rubber flange, were inserted into the abomasum $5 \mathrm{~d}$ before beginning the study (Prom et al., 2021). Infusion lines attached to the infusion devices (0.5-cm diameter polyvinyl chloride tubing) were passed through the rumen fistula and sulcus omasi into the abomasum (Tyburczy et al., 2008). Lines were checked daily throughout the study to ensure proper placement. Infusate solutions were delivered into infusion lines using 60-mL plastic syringes.

All animals received a common diet that was formulated to meet the requirements of the animals as determined by NRC (2001) (Table 2). The diet included a commercially available saturated FA supplement (Energy Booster 100, Milk Specialties Global; Table 2) at $1.9 \%$ diet DM to increase the amount of saturated FA flowing to the small intestine to better evaluate the potential for treatments to improve FA digestibility. The diet was fed during a 14-d preliminary period and throughout the experiment. Dry matter concentration of forages was determined twice weekly, and diets were adjusted when necessary. Cows were housed in individual tiestalls at the Michigan State University Dairy Cattle Teaching and Research Center throughout the experiment and milked twice daily (0400 and $1500 \mathrm{~h}$ ). Access to feed was blocked from 0800 to $1000 \mathrm{~h}$ for collection of orts and offering of new feed. Feed intake was recorded, and cows were offered $115 \%$ of expected intake at $1000 \mathrm{~h}$ daily. Water was available ad libitum 
Table 1. Fatty acid (FA) profile and total FA content of polysorbate supplements infused during treatment periods

\begin{tabular}{lccc}
\hline & & Emulsifier $^{1}$ \\
\cline { 2 - 4 } Item & Polysorbate-C16:0 & Polysorbate-C18:0+C16:0 & Polysorbate-C18:1 \\
\hline Selected individual FA, g/100 g of FA & & & 1.55 \\
C14:0 & 0.38 & 43.4 & 0.26 \\
C16:0 & 4.6 & 48.5 & 4.66 \\
C18:0 & - & 0.32 & 1.41 \\
trans C18:1 & - & 0.11 & 5.23 \\
cis-9 C18:1 & - & 0.32 & 2.35 \\
cis-11 C18:1 & - & - & 0.06 \\
cis-9, cis-12 C18:2 & - & 22.6 & 18.3 \\
cis- ,trans-11 C18:2 & 24.0 & & 18.3 \\
Total FA, $\%$ DM & &
\end{tabular}

${ }^{1}$ Tween (Sigma-Aldrich).

in each stall, and stalls were bedded with sawdust and cleaned twice daily.

\section{Data and Sample Collection}

All samples and data were collected during the last $4 \mathrm{~d}$ of each treatment period (d 15-18). Samples of all diet ingredients and orts from each cow were collected

Table 2. Ingredient and nutrient composition of the diet fed to cows infused with treatments $(\mathrm{n}=8)$

\begin{tabular}{|c|c|}
\hline Item & $\%$ of DM \\
\hline \multicolumn{2}{|l|}{ Ingredient } \\
\hline Corn silage & 29.3 \\
\hline Alfalfa silage & 20.8 \\
\hline Wheat straw & 1.68 \\
\hline Ground corn & 11.5 \\
\hline High moisture corn & 12.3 \\
\hline Soybean meal & 12.0 \\
\hline Soyhulls & 7.74 \\
\hline Vitamin mineral $\operatorname{mix}^{1}$ & 2.84 \\
\hline Fat supplement ${ }^{2}$ & 1.92 \\
\hline \multicolumn{2}{|l|}{ Nutrient composition } \\
\hline $\mathrm{DM}^{3}$ & 54.1 \\
\hline NDF & 32.1 \\
\hline $\mathrm{CP}$ & 15.7 \\
\hline Starch & 25.8 \\
\hline Fatty acids & 3.32 \\
\hline C16:0 & 0.82 \\
\hline C18:0 & 0.78 \\
\hline cis-9 C18:1 & 0.42 \\
\hline cis-9,cis-12 C18:2 & 0.90 \\
\hline cis-9,cis-12,cis-15 C18:3 & 0.17 \\
\hline
\end{tabular}

${ }^{1}$ Vitamin and mineral mix contained $34.1 \%$ dry ground shelled corn, $25.6 \%$ white salt, $21.8 \%$ calcium carbonate, $9.1 \%$ Biofos (The Mosaic Co.), $3.9 \%$ magnesium oxide, $2 \%$ soybean oil, and $<1 \%$ of each of the following: manganese sulfate, zinc sulfate, ferrous sulfate, copper sulfate, iodine, cobalt carbonate, vitamin $\mathrm{E}$, vitamin $\mathrm{A}$, vitamin $\mathrm{D}$, and selenium.

${ }^{2}$ Energy Booster 100 (Milk Specialties Global). Contained (g/100 g of FA) 4.09 of C14:0, 34.2 of C16:0, 47.7 of C18:0, 6.42 of cis-9 C18:1, and 0.89 cis- 9 , cis- 12 C18:2; $80.5 \%$ total FA.

${ }^{3}$ Percent of as-fed diet. daily and composited by period for analysis. Milk yield was recorded, and 2 milk samples were collected at each milking. One aliquot was collected in a sealed tube with preservative (Bronopol tablet; D\&F Control Systems) and stored at $4^{\circ} \mathrm{C}$ for milk component analysis. The second aliquot was stored without preservative at $-20^{\circ} \mathrm{C}$ for $\mathrm{FA}$ composition analysis. Fecal $(\sim 400 \mathrm{~g})$ and blood $(\sim 15 \mathrm{~mL})$ samples were collected every $9 \mathrm{~h}$ over the last $4 \mathrm{~d}$ of each period, totaling 8 samples per cow per period. The 9 -h interval over $4 \mathrm{~d}$ simulated sampling every $3 \mathrm{~h}$ over a 24 -h period to account for diurnal variation. Feces were stored in a sealed plastic cup at $-20^{\circ} \mathrm{C}$. Blood was stored on ice and centrifuged within 30 min at $2,000 \times g$ for 15 min at $4^{\circ} \mathrm{C}$. Plasma was transferred into microcentrifuge tubes and stored at $-20^{\circ} \mathrm{C}$.

Body weight measurements were taken daily during the sampling period following the afternoon milking. On the last day of the preliminary period and last day of each treatment period, 3 trained investigators determined BCS on a 5-point scale in 0.25-point increments (Wildman et al., 1982).

\section{Sample Analysis}

Diet ingredients, orts, and fecal samples were dried at $55^{\circ} \mathrm{C}$ in a forced-air oven for $72 \mathrm{~h}$. Dried fecal samples for each cow were then composited by period. Dried samples were ground with a Wiley mill $(1 \mathrm{~mm}$-screen; Arthur H. Thomas). Feed ingredients were analyzed for absolute DM, ash, NDF, indigestible NDF, CP, and starch, and orts and feces for absolute DM, ash, NDF, and indigestible NDF by Cumberland Valley Analytical Services (Waynesboro, PA) as described by Boerman et al. (2017). Absolute DM was determined by drying samples in an oven at $105^{\circ} \mathrm{C}$ using the National Forage Testing Association reference method (Shreve et al., 2006). Indigestible NDF was estimated as NDF 
after 240-h in vitro fermentation (Goering and Van Soest, 1970) and was used as an internal marker to estimate fecal output to determine apparent total-tract digestibility of nutrients (Cochran et al., 1986). The FA concentrations of feed ingredients, orts, and feces were determined as described by Lock et al. (2013).

Milk samples were analyzed for fat, true protein, and lactose concentrations by mid-infrared spectroscopy (AOAC, 1990; method 972.160; NorthStar Michigan Lab, Grand Ledge, MI). Yields of 3.5\% FCM, ECM, and milk components were calculated using milk yield and component concentrations from each milking, summed for a daily total, and averaged for each collection period. Milk samples used for analysis of FA composition were composited based on milk fat yield (d 15-18 of each period). Milk lipids were extracted and FA-methyl esters prepared and quantified using GLC according to Lock et al. (2013). Yield of individual FA $(\mathrm{g} / \mathrm{d})$ in milk fat were calculated by using milk fat yield and FA concentration to determine yield on a mass basis using the molecular weight of each FA while correcting for glycerol content and other milk lipid classes (Piantoni et al., 2013).

Plasma samples from each cow were composited by period before analysis. All plasma samples were analyzed in duplicate with a coefficient of variation of $<5 \%$ between duplicates. Plasma samples were analyzed at the Michigan State University Veterinary Diagnostic Laboratory (Lansing, MI). Nonesterified FA were quantified using a Beckman Coulter AU series chemistry analyzer (Beckman Coulter). Insulin was quantified with a bovine insulin ELISA using a solid phase 2-site enzyme immunoassay (Mercodia). Glucose was quantified using a glucose oxidase method (PGO Enzyme Product No. P7119, Sigma Chemical Co.).

\section{Statistical Analysis}

All data were analyzed using the mixed model procedure of SAS (version 9.4, SAS Institute) according to the following model:

$$
\mathrm{Y}_{\mathrm{ijkl}}=\mu+\mathrm{Ci}(\mathrm{S})_{\mathrm{i}(\mathrm{j})}+\mathrm{S}_{\mathrm{j}}+\mathrm{P}_{\mathrm{k}}+\mathrm{T}_{1}+\mathrm{e}_{\mathrm{ijkl}},
$$

where $\mathrm{Y}_{\mathrm{ijk} \mathrm{l}}=$ dependent variable, $\mu=$ overall mean, $\mathrm{Ci}$ $(\mathrm{S})_{\mathrm{i}(\mathrm{j})}=$ random effect of cow nested within square (i $=1-4)$, the fixed effect of square $(\mathrm{j}=1-2), \mathrm{P}_{\mathrm{k}}=$ fixed effect of period $(\mathrm{k}=1-4), \mathrm{T}_{1}=$ fixed effect of treatment $(\mathrm{l}=1-4)$, and $\mathrm{e}_{\mathrm{ijkl}}=$ residual error. Two squares, each one with 4 cows, were formed based on lower [milk yield $($ mean $\pm \mathrm{SD})=43.0 \pm 2.46 \mathrm{~kg} / \mathrm{d}]$ and higher (milk yield $=50.5 \pm 3.97 \mathrm{~kg} / \mathrm{d}$ ) production cows. The interactions between period and treatment, period and square, and square and treatment were initially included in the model and removed when $P>0.20$ (de Souza et al., 2020; Prom et al., 2021). Normality of the residuals was checked with normal probability and box plots and homogeneity of variances with plots of residuals versus predicted values. All data are expressed as least squares means and standard error of the means. When the model tended to be significant $(P \leq 0.10)$, the treatment means were compared using the protected least significant difference test with significant differences declared at $P \leq 0.05$ and tendencies at 0.05 $<P \leq 0.10$.

\section{RESULTS}

\section{Nutrient Intake and Total-Tract Digestibility}

There were no effects of treatments on DMI $(P=$ $0.25)$, NDF intake $(P=0.60), 18$-carbon $\mathrm{FA}$ intake $(P=0.43)$, total FA intake $(P=0.48)$, or DM digestibility $(P=0.45$, Table 3$)$. The T40 treatment tended to increase 16-carbon FA intake $(P=0.06)$ compared with CON and increased it compared with T60 (8.00 $\mathrm{g} / \mathrm{d}, P=0.04)$ and T80 (9.00 g/d, $P=0.02)$. Both T40 and T80 tended to increase NDF digestibility compared with $\mathrm{CON}(P=0.10)$ and increased it compared with T60 $(P=0.05)$.

Compared with CON, T80 treatment increased total, $16-$, and 18-carbon FA digestibility by $5.40(P=0.02)$, 4.80 , and 5.70 percentage units $(P=0.01)$, respectively. The T80 treatment tended to increase total FA digestibility compared with T40 $(P=0.08)$ and increased it compared with T60 (3.90 percentage units, $P=0.02$ ). In addition, T80 increased 16-carbon FA digestibility compared with T60 (3.40 percentage units, $P=0.03$ ). The T80 treatment increased 18-carbon FA digestibility compared with T40 (4.00 percentage units, $P=0.04$ ) and T60 (4.30 percentage units, $P=0.02$ ). Also, T40 tended to increase 16-carbon FA digestibility compared with CON $(P=0.06$, Table 3$)$.

The T80 treatment increased total FA absorption compared with CON $(53 \mathrm{~g} / \mathrm{d})$ and T60 $(52 \mathrm{~g} / \mathrm{d}, P=$ $0.02)$. The T40 treatment tended to increase total FA absorption compared with CON $(P=0.10)$ and T60 $(P$ $=0.07)$. Both the T40 and T80 treatments increased the absorption of 16-carbon FA compared with CON $(11.0$ and $10.0 \mathrm{~g} / \mathrm{d})$ and T60 (10.0 and $9.00 \mathrm{~g} / \mathrm{d}, P \leq$ $0.04)$, respectively. The T80 treatment increased the absorption of 18-carbon FA compared with the other treatments, CON $(36.0 \mathrm{~g} / \mathrm{d}, P=0.01)$, T40 $(27 \mathrm{~g} / \mathrm{d}$, $P=0.05)$, and T60 (36.0 $\mathrm{g} / \mathrm{d}, P=0.01)$. The T60 treatment did not differ from $\mathrm{CON}$ for any variable $(P$ $\geq 0.16$, Table 3 ). 
Table 3. Nutrient intake and apparent total-tract digestibility of cows infused with treatments $(\mathrm{n}=8)$

\begin{tabular}{|c|c|c|c|c|c|c|}
\hline \multirow[b]{2}{*}{ Variable } & \multicolumn{4}{|c|}{ Treatment $^{1}$} & \multirow[b]{2}{*}{ SEM } & \multirow[b]{2}{*}{$P$-value ${ }^{2}$} \\
\hline & $\mathrm{CON}$ & $\mathrm{T} 40$ & T60 & $\mathrm{T} 80$ & & \\
\hline \multicolumn{7}{|l|}{ Intake, $\mathrm{kg} / \mathrm{d}$} \\
\hline DM & 27.2 & 27.2 & 26.6 & 26.6 & 0.79 & 0.25 \\
\hline NDF & 8.79 & 8.81 & 8.61 & 8.59 & 0.30 & 0.60 \\
\hline \multicolumn{7}{|l|}{ Intake, $\mathrm{g} / \mathrm{d}$} \\
\hline Total fatty acid (FA) & 942 & 951 & 928 & 940 & 24.7 & 0.48 \\
\hline 16-carbon FA & $224^{\mathrm{ab}}$ & $231^{\mathrm{a}}$ & $223^{\mathrm{b}}$ & $222^{\mathrm{b}}$ & 5.52 & 0.09 \\
\hline 18-carbon FA & 654 & 652 & 642 & 651 & 16.0 & 0.43 \\
\hline \multicolumn{7}{|l|}{ Digestibility, \% } \\
\hline $\mathrm{DM}$ & 64.1 & 65.0 & 63.6 & 64.9 & 0.76 & 0.45 \\
\hline $\mathrm{NDF}$ & $45.3^{\mathrm{ab}}$ & $47.1^{\mathrm{a}}$ & $44.3^{\mathrm{b}}$ & $47.3^{\mathrm{a}}$ & 1.99 & 0.09 \\
\hline Total FA & $67.7^{\mathrm{b}}$ & $70.2^{\mathrm{ab}}$ & $69.2^{\mathrm{b}}$ & $73.1^{\mathrm{a}}$ & 1.56 & 0.05 \\
\hline 16-carbon FA & $67.4^{\mathrm{b}}$ & $70.3^{\mathrm{ab}}$ & $68.8^{\mathrm{b}}$ & $72.2^{\mathrm{a}}$ & 1.35 & 0.04 \\
\hline 18-carbon FA & $67.7^{\mathrm{b}}$ & $69.4^{\mathrm{b}}$ & $69.1^{\mathrm{b}}$ & $73.4^{\mathrm{a}}$ & 1.87 & 0.04 \\
\hline \multicolumn{7}{|l|}{ Absorbed, g/d } \\
\hline Total FA & $638^{\mathrm{b}}$ & $670^{\mathrm{ab}}$ & $639^{\mathrm{b}}$ & $691^{\mathrm{a}}$ & 11.8 & 0.05 \\
\hline 16-carbon FA & $152^{\mathrm{b}}$ & $163^{\mathrm{a}}$ & $153^{\mathrm{b}}$ & $162^{\mathrm{a}}$ & 2.98 & 0.06 \\
\hline 18-carbon FA & $442^{\mathrm{b}}$ & $451^{\mathrm{b}}$ & $442^{\mathrm{b}}$ & $478^{\mathrm{a}}$ & 8.95 & 0.03 \\
\hline
\end{tabular}

${ }^{\mathrm{a}, \mathrm{b}}$ For the effect of treatment, means in a row with different superscripts differ $(P<0.05)$. Separation conducted only if treatment effect was $P<0.10$.

${ }^{1}$ Treatments were as follows: $\mathrm{CON}=$ no emulsifier infusion (water only); T40 = infusion of $30 \mathrm{~g} / \mathrm{d}$ of polysorbate-C16:0; T60 = infusion of $30 \mathrm{~g} / \mathrm{d}$ of polysorbate-C18:0+C16:0; T80 = infusion of $30 \mathrm{~g} / \mathrm{d}$ of polysorbate-

C18:1.

${ }^{2} P$-values refer to the effect of treatment.

\section{Production Responses}

Treatments did not affect the yields of milk $(P=$ $0.75), \operatorname{ECM}(P=0.27)$, milk protein $(P=0.49)$, and milk lactose $(P=0.76)$, or the contents of milk protein
$(P=0.13)$ and milk lactose $(P=0.76), \mathrm{BW}(P=0.87)$, or BCS $(P=0.91$, Table 4$)$. The T80 treatment increased the yields of milk fat and $3.5 \%$ FCM compared with CON (0.21 and $3.10 \mathrm{~kg} / \mathrm{d})$ and T60 (0.11 and $2.00 \mathrm{~kg} / \mathrm{d}, P \leq 0.03)$, respectively. The T40 treatment

Table 4. Milk yield, milk composition, BW, and BCS of cows infused with treatments $(\mathrm{n}=8)$

\begin{tabular}{|c|c|c|c|c|c|c|}
\hline \multirow[b]{2}{*}{ Variable } & \multicolumn{4}{|c|}{ Treatment $^{1}$} & \multirow[b]{2}{*}{ SEM } & \multirow[b]{2}{*}{$P$-value ${ }^{2}$} \\
\hline & $\mathrm{CON}$ & $\mathrm{T} 40$ & T60 & $\mathrm{T} 80$ & & \\
\hline \multicolumn{7}{|l|}{ Yield, kg/d } \\
\hline Milk & 45.4 & 45.3 & 44.8 & 44.9 & 1.15 & 0.75 \\
\hline $3.5 \% \mathrm{FCM}^{3}$ & $43.8^{\mathrm{c}}$ & $46.5^{\mathrm{ab}}$ & $44.5^{\mathrm{bc}}$ & $46.9^{\mathrm{a}}$ & 2.36 & 0.06 \\
\hline $\mathrm{ECM}^{4}$ & 44.0 & 45.9 & 44.5 & 46.2 & 1.72 & 0.27 \\
\hline Fat & $1.49^{\mathrm{c}}$ & $1.66^{\mathrm{ab}}$ & $1.55^{\mathrm{bc}}$ & $1.70^{\mathrm{a}}$ & 0.12 & 0.04 \\
\hline Protein & 1.40 & 1.40 & 1.38 & 1.36 & 0.05 & 0.49 \\
\hline Lactose & 2.26 & 2.24 & 2.23 & 2.23 & 0.06 & 0.76 \\
\hline \multicolumn{7}{|l|}{ Milk composition, $\%$} \\
\hline Fat & $3.33^{\mathrm{c}}$ & $3.69^{\mathrm{ab}}$ & $3.50^{\mathrm{bc}}$ & $3.79^{\mathrm{a}}$ & 0.23 & 0.03 \\
\hline Protein & 3.09 & 3.10 & 3.10 & 3.04 & 0.08 & 0.13 \\
\hline Lactose & 4.97 & 4.95 & 4.96 & 4.96 & 0.03 & 0.87 \\
\hline $3.5 \% \mathrm{FCM} / \mathrm{DMI}, \mathrm{kg} / \mathrm{kg}$ & $1.62^{\mathrm{b}}$ & $1.70^{\mathrm{ab}}$ & $1.68^{\mathrm{ab}}$ & $1.75^{\mathrm{a}}$ & 0.05 & 0.08 \\
\hline $\mathrm{BW}, \mathrm{kg}$ & 649 & 652 & 649 & 651 & 12.9 & 0.87 \\
\hline BCS & 3.07 & 3.08 & 3.08 & 3.06 & 0.07 & 0.91 \\
\hline
\end{tabular}

${ }^{a-c}$ For the effect of treatment, means in a row with different superscripts differ $(P<0.05)$. Separation conducted only if treatment effect was $P<0.10$.

${ }^{1}$ Treatments were as follows: $\mathrm{CON}=$ no emulsifier infusion (water only); $\mathrm{T} 40=$ infusion of $30 \mathrm{~g} / \mathrm{d}$ of polysorbate-C16:0; T60 = infusion of $30 \mathrm{~g} / \mathrm{d}$ of polysorbate-C18:0+C16:0; T80 = infusion of $30 \mathrm{~g} / \mathrm{d}$ of polysorbateC18:1.

${ }^{2} P$-values refer to the effect of treatment.

${ }^{3} 3.5 \% \mathrm{FCM}=[(0.4324 \times \mathrm{kg}$ of milk $)+(16.216 \times \mathrm{kg}$ of milk fat $)](\mathrm{NRC}, 2001)$.

${ }^{4} \mathrm{ECM}=[(0.327 \times \mathrm{kg}$ of milk $)+(12.95 \times \mathrm{kg}$ of milk fat $)+(7.20 \times \mathrm{kg}$ of milk protein $)]$. This equation corrects milk to a $0.68 \mathrm{Mcal} / \mathrm{kg}$ energy basis (Tyrrell and Reid, 1965). 
Table 5. Milk fatty acid yields and contents by source of cows infused with treatments $(\mathrm{n}=8)$

\begin{tabular}{|c|c|c|c|c|c|c|}
\hline \multirow[b]{2}{*}{ Variable } & \multicolumn{4}{|c|}{ Treatment $^{1}$} & \multirow[b]{2}{*}{ SEM } & \multirow[b]{2}{*}{$P$-value ${ }^{2}$} \\
\hline & $\mathrm{CON}$ & $\mathrm{T} 40$ & T60 & $\mathrm{T} 80$ & & \\
\hline \multicolumn{7}{|c|}{ Summation by source, ${ }^{3} \mathrm{~g} / \mathrm{d}$} \\
\hline De novo & $361^{\mathrm{b}}$ & $416^{\mathrm{a}}$ & $388^{\mathrm{ab}}$ & $411^{\mathrm{a}}$ & 25.3 & 0.02 \\
\hline Mixed & $542^{\mathrm{c}}$ & $611^{\mathrm{a}}$ & $562^{\mathrm{bc}}$ & $597^{\mathrm{ab}}$ & 54.2 & 0.06 \\
\hline Preformed & $475^{\mathrm{c}}$ & $519^{\mathrm{b}}$ & $500^{\mathrm{b}}$ & $556^{\mathrm{a}}$ & 26.8 & $<0.01$ \\
\hline \multicolumn{7}{|c|}{ Summation by source ${ }^{3} \mathrm{~g} / 100 \mathrm{~g}$} \\
\hline De novo & 27.1 & 27.4 & 26.6 & 27.4 & 0.53 & 0.40 \\
\hline Mixed & $38.7^{\mathrm{a}}$ & $39.1^{\mathrm{a}}$ & $38.5^{\mathrm{a}}$ & $37.5^{\mathrm{b}}$ & 0.84 & 0.03 \\
\hline Preformed & 34.2 & 33.4 & 34.9 & 35.0 & 1.07 & 0.16 \\
\hline \multicolumn{7}{|c|}{$\begin{array}{l}\text { a-c For the effect of treatment, means in a row with different superscripts differ }(P<0.05) \text {. Separation con } \\
\text { ducted only if treatment effect was } P<0.10 \text {. }\end{array}$} \\
\hline \multicolumn{7}{|c|}{$\begin{array}{l}{ }^{1} \text { Treatments were as follows: } \mathrm{CON}=\text { no emulsifier infusion (water only); T40 }=\text { infusion of } 30 \mathrm{~g} / \mathrm{d} \text { of polysor- } \\
\text { bate-C16:0; T60 }=\text { infusion of } 30 \mathrm{~g} / \mathrm{d} \text { of polysorbate-C18:0+C16:0; T80 }=\text { infusion of } 30 \mathrm{~g} / \mathrm{d} \text { of polysorbate- } \\
\mathrm{C} 18: 1 . \\
{ }^{2} P \text {-values refer to the effect of treatment. }\end{array}$} \\
\hline \multicolumn{7}{|c|}{$\begin{array}{l}{ }^{3} \text { De novo fatty acids originate from mammary de novo synthesis }(<16 \text { carbons), preformed fatty acids originate } \\
\text { from extraction from plasma ( }>16 \text { carbons), and mixed fatty acids originate from both sources (C16:0 plus } \\
\text { cis-9 C16:1). }\end{array}$} \\
\hline
\end{tabular}

increased the yields of milk fat $(0.17 \mathrm{~kg} / \mathrm{d}, P=0.02)$ and $3.5 \% \mathrm{FCM}(2.70 \mathrm{~kg} / \mathrm{d}, P=0.04)$ compared with $\mathrm{CON}$ and tended to increase both variables compared with T60 $(P \leq 0.10$, Table 4$)$.

Compared with CON, both T40 (0.36 g/100 g, $P=$ $0.02)$ and $\mathrm{T} 80(0.46 \mathrm{~g} / 100 \mathrm{~g}, P=0.01)$ increased milk fat content, and T60 tended to increase it $(P=0.10)$. In addition, T80 also increased milk fat content compared with T60 (0.10 g/100 g, $P=0.04)$. Compared with CON, T80 increased feed efficiency $(3.5 \% \mathrm{FCM} / \mathrm{DMI}$, $0.08 \mathrm{~kg} / \mathrm{kg}, P=0.02)$, and T40 tended to increase it $(P$ $=0.08$, Table 4).

\section{Milk FA Yields and Contents}

Milk FA are derived from either de novo synthesis in the mammary gland $(<16$ carbon FA) or preformed FA extracted from plasma ( $>16$ carbon FA). Mixed-source FA (16-carbon) can be derived from either source. Compared with CON, both T40 $(55 \mathrm{~g} / \mathrm{d})$ and T80 (50.0 $\mathrm{g} / \mathrm{d})$ increased the yield of de novo milk FA $(P \leq 0.01$, Table 5) by increasing the yields of milk FA from C4:0 to C14:0 ( $P \leq 0.05$, Supplemental Table S1, https://dx .doi.org/10.5281/zenodo.5841566). The T40 treatment increased the yield of mixed milk FA compared with CON $(69.0 \mathrm{~g} / \mathrm{d}, P=0.02)$ and T60 $(49.0 \mathrm{~g} / \mathrm{d}, P=0.05$, Table 5). Also, T80 increased the yield of mixed milk FA compared with CON $(55.0 \mathrm{~g} / \mathrm{d}, P=0.04$, Table 5$)$. All mixed milk FA increases were driven by increases in the yield of C16:0 ( $P \leq 0.04$, Supplemental Table S1). The T80 treatment increased the yield of preformed milk FA compared with the other treatments $(P \leq$ 0.03, Table 5). The major preformed milk FA increased by T80 were C18:0, cis-9 C18:1, cis-9,cis-12 C18:2, and cis-9,cis-12,cis-15 C18:3 ( $P \leq 0.03$; Supplemental Table S1). Both T40 and T60 also increased the yield of preformed milk FA compared with CON $(P \leq 0.01$. Table 5 ), wherein the major FA increased by T40 were cis-9 C18:1 $(P=0.02)$, cis-9,cis-12 C18:2 $(P=0.01)$, and cis-9,cis-12,cis-15 C18:3 $(P=0.02)$; however, T60 only increased cis-9 C18:1 $(P=0.03$, Supplemental Table $\mathrm{S} 1)$.

On a content basis, except for mixed milk FA ( $P=$ $0.03)$ and $\mathrm{C} 16: 0(P=0.01)$, treatments had no effect on the content of milk FA $(P \geq 0.16$, Table 5, Supplemental Table S2, https://dx.doi.org/10.5281/zenodo .5841566). We observed that T80 decreased the content of mixed milk FA compared with the other treatments $(P \leq 0.03$, Table 5$)$ due to a decrease in the content of C16:0 $(P \leq 0.01$, Supplemental Table S2).

\section{Plasma Hormones and Metabolites}

There were no effects of treatment on plasma concentrations of nonesterified FA $(P=0.13)$, insulin $(P$ $=0.21)$, or glucose $(P=0.67$, Supplemental Table S3, https://dx.doi.org/10.5281/zenodo.5841566).

\section{DISCUSSION}

To our knowledge, the only previous study that has examined the effects of polysorbates on FA digestion in ruminants is our recent study by de Souza et al. (2020). In that study, we postulated that emulsifying limitations in the intestine is probably one of the reasons for reduced FA digestibility as the flow of FA to the intestine increases in dairy cows. We observed that abomasal infusion of polysorbate-C18:1, a polye- 
thoxylated sorbitan esterified mostly with cis-9 C18:1 $(\sim 84 \%)$, quadratically improved FA digestibility and absorption when infused up to $30 \mathrm{~g} / \mathrm{d}$. However, although the polysorbate family of surfactants all contain the same base polyethoxylated sorbitan, they can differ in the FA esterified to it. For example, in addition to polysorbate-C18:1, polysorbate-C16:0 is esterified mostly with C16:0 ( $94 \%)$, and polysorbate -C18:0+C16:0 predominantly with $\mathrm{C} 18: 0$ and $\mathrm{C} 16: 0$ ( $\sim 49 \% \mathrm{C} 18: 0, \sim 43 \% \mathrm{C} 16: 0)$. These differences in FA composition between the various polysorbates should be considered as micelle formation and stability can be affected by the profile of $\mathrm{FA}$ in the small intestine (Hofmann, 1963). However, to our knowledge, no study has previously compared the effects of polysorbates with different FA profiles on nutrient digestibility and production responses of lactating dairy cows.

We did not observe any effect of treatment on DMI. Although the role of the polyethoxylated sorbitan itself is not clear, the predominant FA present in both T40 and T60 are SFA, and supplemental SFA do not generally affect DMI (dos Santos Neto et al., 2021a). The reduction of DMI due to FA supplementation is mainly associated with the action of UFA (dos Santos Neto et al., 2021b), which stimulate the secretion of gut hormones related to satiety (Allen, 2000; Relling and Reynolds, 2007; Bradford et al., 2008). This effect, however, seems to be dose-related, as abomasally infusing $45 \mathrm{~g} / \mathrm{d}$ of polysorbate-C18:1 tended to decrease DMI, but $30 \mathrm{~g} / \mathrm{d}$ had no effect (de Souza et al., 2020). In our current study, infusing $30 \mathrm{~g} / \mathrm{d}$ of T80 also did not decrease DMI. Our results agreed with previous findings where feeding other types of emulsifiers had no effect on DMI of beef (Shain et al., 1993) or dairy cows (Rico et al., 2017; Lee et al., 2019); however, a recent study feeding deoiled soy lecithin up to $0.36 \%$ diet DM showed a linear decrease in DMI (Fontoura et al., 2021). Accordingly, intake of NDF was not affected by treatment, but we observed that both $\mathrm{T} 40$ and $\mathrm{T} 80$ tended to increase NDF digestibility compared with CON. The effect on NDF digestibility could be due to increased rumen retention time caused by gut peptide signaling (Harvatine and Allen, 2006) affecting NDF digestibility without affecting DMI. Piantoni et al. (2013) observed no effect of C16:0 supplementation on DMI and associated the increase in NDF digestibility with the increased plasma cholecystokinin concentration, which increased retention time. Also, in vitro studies using polysorbates observed positive effects on microbial population, ruminal fermentation, and fiber digestion (Kamande et al., 2000; Goto et al., 2003; Lee and $\mathrm{Ha}, 2003)$. Therefore, another possible mechanism might be associated with T40 and T80 increasing hindgut NDF digestion in our study. If the polysorbates had been included in the diets or ruminally infused, the possible alterations to the microbial population in the rumen would also likely affect NDF digestibility. Differences among dietary inclusion and abomasally- and ruminally-infused polysorbate should be examined in the future.

Similar to our previous study (de Souza et al., 2020), we observed that T80 increased the digestibility and absorption of total, 16-, and 18-carbon FA compared with CON. Previous studies with nonruminants found that the dietary inclusion of exogenous emulsifiers such as lysophospholipids and 1,3-diacylglycerol increased fat digestibility in pigs and broilers (Zhao et al., 2015, 2017; Upadhaya et al., 2017). Alternatively, limited information is available on the effects of exogenous emulsifiers on FA digestibility in ruminants. Jenkins and Fotouhi (1990) reported that feeding lecithin to sheep had no effect on FA digestibility. Likewise, including deoiled soy lecithin from 0 to $0.36 \%$ diet DM had no effect on total FA digestibility of cows supplemented with C16:0 (Fontoura et al., 2021). Previously, the same $30 \mathrm{~g} / \mathrm{d}$ dose of polysorbate-C18:1 infused abomasally increased total, 16-, and 18-carbon FA digestibility by 10.2, 8.70, and 11.3 percentage units, respectively (de Souza et al., 2020). Those digestibility increases were greater than those observed in our current study $(5.40,4.48$, and 5.70 percentage units for total, 16-, and 18-carbon FA). Further studies are needed to examine the effects of exogenous emulsifiers on cows under different intake levels, stages of lactation, and physiological conditions.

We also observed that T80 increased the digestibility and absorption of total, 16-, and 18-carbon FA compared with T60 and tended to increase the digestibility of total FA and increased the digestibility and absorption of 18-carbon FA compared with T40. Although it is challenging to differentiate between the effects of the polyethoxylated sorbitan and the attached FA, the effects of T80 on FA digestibility supported our hypothesis that a polysorbate containing cis-9 C18:1 has the largest effect on FA digestibility. Increasing the unsaturation of a FA imparts amphiphilic qualities to the FA by increasing the dissymmetry between polar and nonpolar regions (Hofmann, 1963). Also, UFA require a shorter length of the intestine for absorption than SFA (Freeman, 1969; Ockner et al., 1972). Freeman (1969) solidified the basic mechanisms by which FA exert differing effects on micelle formation, and thus FA absorption. This work characterized factors that influence FA absorption in sheep and found that the critical micellar concentration for cis-9 C18:1 is $60 \%$ lower than that for C18:0, meaning micelles will begin to form at a lower concentration for cis-9 C18:1 than for C18:0. Furthermore, Freeman (1969) found that cis-9 C18:1 was 6 and 14 times more soluble in a dilute bile salt solution 
than $\mathrm{C} 16: 0$ and C18:0, respectively. A recent study fed either a control diet not supplemented with FA or diets supplemented with FA blends at $1.5 \%$ diet DM that contained either 80\% C16:0, 40\% C16:0 + 40\% C18:0, or $45 \% \mathrm{C} 16: 0+35 \%$ cis-9 $\mathrm{C} 18: 1$. In this study, including cis-9 C18:1 in the supplemental FA blend increased total FA digestibility (de Souza et al., 2018). Other feeding studies have also demonstrated increased FA digestibility in diets supplemented with cis-9 C18:1 compared with diets that included SFA supplements (Western et al., 2020b; Burch et al., 2021; Prom and Lock, 2021). In our current study, the T80 treatment contained $\sim 5 \mathrm{~g} / \mathrm{d}$ of cis- $9 \mathrm{C} 18: 1$ and increased total FA absorption by $53.0 \mathrm{~g} / \mathrm{d}$. By comparison, abomasally infusing cis-9 C18:1 at $20 \mathrm{~g} / \mathrm{d}$ increased total FA absorption by $87.0 \mathrm{~g} / \mathrm{d}$ (Prom et al., 2021). Future research is required to directly compare abomasal infusions of T80 and cis-9 C18:1 to better understand specific effects of polysorbates and cis-9 C18:1.

Interestingly, we also observed that T40 tended to increase the digestibility of 16-carbon FA compared with CON. However, the results disagreed with our hypothesis that all polysorbates examined would improve FA digestibility, as T60 surprisingly had no effect compared with CON. The lack of effect observed with T60 may be due to the negative effect of the attached C18:0. As mentioned previously, C18:0 has very low solubility and is less incorporated into micelles, affecting its digestibility (Freeman, 1969; Smith and Lough, 1976). Even though differences in FA absorption in response to the profile of FA reaching the duodenum have been well demonstrated in the bovine, the effect of the attached FA in the current study was surprising as the infusates only contained 7,7 , and $6 \mathrm{~g} / \mathrm{d}$ of FA for T40, T60, and T80, respectively. Previous studies, however, have consistently shown that increasing dietary C18:0 decreases FA digestibility. A meta-analysis by Boerman et al. (2015) reported that increasing the flow of C18:0 to the duodenum linearly decreased the digestibilities of total, 16-, and 18-carbon FA. The inclusion of an almost pure C18:0 supplement (>90\% C18:0) at $1.92 \%$ (Piantoni et al., 2015) and 2.30\% (Boerman et al., 2017) diet DM reduced FA digestibility of lactating dairy cows by 20 and 28 percentage units, respectively. When included at $1.95 \%$ in the diet DM, a C18: 0-enriched supplement $(92.6 \% \mathrm{C} 18: 0)$ decreased total and 16-carbon FA absorption compared with a C16: 0-enriched supplement (91.0\% C16:0; Shepardson and Harvatine, 2021). Our recent meta-analysis observed that diets containing mixed C16:0 + C18:0 supplements decreased FA digestibility by 5.20 percentage units compared with control diets not supplemented with FA, whereas diets with C16:0-enriched supplements had no effect (dos Santos Neto et al., 2021a).
Similarly, we observed that T40 increased 16-carbon FA absorption and tended to increase total FA absorption compared with T60. Increasing chain length reduces the solubility coefficient of saturated FA (Scrimgeour and Harwood, 2007). Therefore, these differences in FA absorption between T40 and T60 may be due to the increased ability of C16:0 to form micelles. Our study demonstrates that digestion responses are clearly affected by the FA present in the polysorbate. However, the underlying mechanisms associated with the isolated action of the polyethoxylated sorbitan are still not fully understood. This topic deserves further attention.

We observed no treatment effects on milk yield in this study, but both T40 and T80 increased the content and yield of milk fat and, consequently, 3.5\% FCM compared with CON. These results are likely related to the improvements observed in FA digestibility, which increased FA available to the mammary gland. Similarly, abomasal infusion of polysorbate-C18:1 (30 g/d) in the study by de Souza et al. (2020) did not affect milk yield but increased the yields of milk fat and 3.5\% FCM.

We observed that both T40 and T80 increased the yields of de novo, mixed, and preformed milk FA compared with CON. de Souza et al. (2020) also observed that polysorbate-C18:1 increased the yield of FA from de novo, mixed, and preformed sources. Similarly, we also observed that increasing total FA absorption by feeding high-fat basal diets (by increasing whole cottonseed) increased the yields of de novo, mixed, and preformed milk FA compared with low-fat basal diets (Rico et al., 2017; de Souza et al., 2018). All these results are consistent with the meta-analysis by Glasser et al. (2008) in which they proposed that the synthesis of de novo FA in the mammary gland depends on the supply of long-chain FA. This occurs because FA are sequentially esterified to the positions $s n-1, s n-2$, or $s n-3$ of the glycerol-3-phosphate backbone. Thus, de novo FA are predominantly incorporated at sn-3 only after a large part of 16- and 18-carbon FA have been added at $s n-1$ and $s n-2$ (Jensen, 2002; Glasser et al., 2008; Månsson, 2008). A substitution effect of de novo by preformed FA is also a very common observation in FA-supplemented diets (Glasser et al., 2008; He et al., 2012; dos Santos Neto et al., 2021b). The interactions between FA-supplemented diets and exogenous emulsifiers on milk FA sources requires further research.

In the study by de Souza et al. (2020), C16:0 was the major FA increased in milk when polysorbate-C18:1 was infused up to $30 \mathrm{~g} / \mathrm{d}$. We observed the same results in our current study. The greater increase in the yield of C16:0 may be due to the uniform distribution of this FA between the $s n-1(44.1 \%)$ and $s n-2(45.2 \%)$ positions of the glycerol-3-phosphate backbone. Also, the 
enzyme glycerol-3-phosphate acyltransferase, responsible for adding a fatty acyl-CoA to the $s n-1$ position, has a higher preference for C16:0 (8 to 10-fold) as a substrate than for C18:0 or cis-9 C18:1 (Kinsella and Gross, 1973; Jensen, 2002; Tzompa-Sosa et al., 2014). Additionally, both T40 and T80 increased the yield of preformed FA compared with CON, but T80 increased the yields of more individual 18-carbon FA. Hence, T80 had a higher yield of preformed FA compared with T40. In line with the results obtained for FA absorption, because T60 did not improve FA digestibility, it did not affect the yields of de novo, mixed, or preformed milk FA compared with CON. It is noteworthy that the use of different exogenous emulsifiers can potentially alter the milk FA profile of milk fat.

We observed that T40 tended to improve and T80 improved feed efficiency $(3.5 \% \mathrm{FCM} / \mathrm{DMI})$ due to the increases in milk fat yield. There were no treatment effects on BW or BCS; however, studies using a larger sample size and longer period lengths are often necessary to see effects on these variables. Other studies suggest that the profile of FA reaching the small intestine may affect energy partitioning (de Souza et al., 2018, 2019); therefore, differences between the polysorbate treatments could potentially affect body tissue reserves in studies specifically designed to examine these variables. It should be noted that insulin, which is a key regulator of nutrient utilization, was increased by dietary cis-9 C18:1 in previous studies (de Souza et al., 2018, 2019; Prom and Lock, 2021) but was not affected by any treatment in our study. Also, de Souza et al. (2020) did not observe changes in plasma concentrations of insulin and glucose when $30 \mathrm{~g} / \mathrm{d}$ of polysorbate -C18:1was abomasally infused.

\section{CONCLUSIONS}

Not all exogenous emulsifiers increased FA digestibility. Compared with CON, T80 increased the digestibility and absorption of total, 16-, and 18-carbon FA. The T40 treatment tended to increase 16-carbon FA digestibility and total FA absorption. As a consequence, both T80 and T40 increased the yields of milk fat and $3.5 \%$ FCM compared with CON. There was no effect of T60 on digestibility or production variables. Milk fat yield increased due to increases in all sources of milk FA (de novo, mixed, and preformed). In addition to the responses obtained compared with CON, T80 increased the digestibility and absorption of total, 16-, and 18-carbon FA compared with T60, and increased the digestibility and absorption of 18-carbon FA compared with T40. These results suggest that the predominant FA present in polysorbates affect its ability to improve
FA digestibility because T80 (polysorbate-C18:1) produced the best responses. The effect of the attached FA may be greater than we anticipated, and future work should directly compare abomasal infusions of polysorbate-C18:1 and cis-9 C18:1.

\section{ACKNOWLEDGMENTS}

Funding for this research was provided by the Michigan Alliance for Animal Agriculture (East Lansing, MI). Crystal Prom was supported by a Pre-Doctoral Fellowship from USDA National Institute of Food and Agriculture (Washington, DC). Any opinions, findings, conclusions, or recommendations expressed in this publication are those of the authors and do not necessarily reflect the view of the U.S. Department of Agriculture. Support was also provided by Global AgriTrade (Rancho Dominguez, CA) and Perdue AgriBusiness (Salisbury, MD) to the Michigan State University Dairy Nutrition Graduate Fellowship Program that supported J. M. dos Santos Neto. We acknowledge L. Worden, J. de Souza, M. Western, J. Guy, H. Sharrard, E. Butler, A. Negreiro, A. Pineda, and A. Burch (all in the Department of Animal Science, Michigan State University, East Lansing) and the staff of the Michigan State University Dairy Cattle Teaching \& Research Center (East Lansing) for their assistance with this experiment. The authors have not stated any conflicts of interest.

\section{REFERENCES}

Ahn, G. C., J. H. Kim, E. K. Park, Y. K. Oh, G. Y. Lee, J. Lee, C. M. Kim, and K. K. Park. 2009. Effects of non-ionic surfactant supplementation on ruminal fermentation, nutrient digestibility and performance of beef steers fed high-roughage diets. AsianAustralas. J. Anim. Sci. 22:993-1004. https://doi.org/10.5713/ ajas.2009.90095.

Allen, M. S. 2000. Effects of diet on short-term regulation of feed intake by lactating dairy cattle. J. Dairy Sci. 83:1598-1624. https:// doi.org/10.3168/jds.S0022-0302(00)75030-2.

AOAC. 1990. Official Methods of Analysis. Vol. 2. 15th ed. AOAC International.

Boerman, J. P., J. de Souza, and A. L. Lock. 2017. Milk production and nutrient digestibility responses to increasing levels of stearic acid supplementation of dairy cows. J. Dairy Sci. 100:2729-2738. https://doi.org/10.3168/jds.2016-12101.

Boerman, J. P., J. L. Firkins, N. R. St-Pierre, and A. L. Lock. 2015 Intestinal digestibility of long-chain fatty acids in lactating dairy cows: A meta-analysis and meta-regression. J. Dairy Sci. 98:88898903. https://doi.org/10.3168/jds.2015-9592.

Bradford, B. J., K. J. Harvatine, and M. S. Allen. 2008. Dietary unsaturated fatty acids increase plasma glucagon-like peptide- 1 and cholecystokinin and may decrease premeal ghrelin in lactating dairy cows. J. Dairy Sci. 91:1443-1450. https://doi.org/10.3168/ jds. 2007-0670

Burch, A. M., A. Pineda, and A. L. Lock. 2021. Effect of palmitic acid-enriched supplements containing stearic or oleic acid on nutrient digestibility and milk production of low-and high-producing 
dairy cows. J. Dairy Sci. 104:8673-8684. https://doi.org/10.3168/ jds.2020-19913.

Carey, M. C., and D. M. Small. 1970. The characteristics of mixed micellar solutions with particular reference to bile. Am. J. Med. 49:590-608. https://doi.org/10.1016/S0002-9343(70)80127-9.

Carey, M. C., D. M. Small, and C. M. Bliss. 1983. Lipid digestion and absorption. Annu. Rev. Physiol. 45:651-677. https://doi.org/ 10.1146/annurev.ph.45.030183.003251.

Cochran, R. C., D. C. Adams, J. D. Wallace, and M. L. Galyean. 1986. Predicting digestibility of different diets with internal markers: evaluation of four potential markers. J. Anim. Sci. 63:1476-1483. https://doi.org/10.2527/jas1986.6351476x.

Cong, Z. H., S. X. Tang, Z. L. Tan, Z. H. Sun, C. S. Zhou, X. F. Han, M. Wang, and G. P. Ren. 2009. Effects of different nonionic surfactants on in vitro fermentation characteristics of cereal straws. J. Anim. Sci. 87:1085-1096. https://doi.org/10.2527/jas.2008-1316.

de Souza, J., C. L. Preseault, and A. L. Lock. 2018. Altering the ratio of dietary palmitic, stearic, and oleic acids in diets with or without whole cottonseed affects nutrient digestibility, energy partitioning, and production responses of dairy cows. J. Dairy Sci. 101:172-185. https://doi.org/10.3168/jds.2017-13460.

de Souza, J., N. R. St-Pierre, and A. L. Lock. 2019. Altering the ratio of dietary C16:0 and cis-9 C18:1 interacts with production level in dairy cows: Effects on production responses and energy partitioning. J. Dairy Sci. 102:9842-9856. https://doi.org/10.3168/jds.2019 -16374 .

de Souza, J., M. Westerrn, and A. L. Lock. 2020. Abomasal infusion of exogenous emulsifier improves fatty acid digestibility and milk fat yield of lactating dairy cows. J. Dairy Sci. 103:6167-6177. https:/ /doi.org/10.3168/jds.2020-18239.

Doreau, M., and A. Ferlay. 1994. Digestion and utilisation of fatty acids by ruminants. Anim. Feed Sci. Technol. 45:379-396. https:/ /doi.org/10.1016/0377-8401(94)90039-6.

dos Santos Neto, J. M., J. de Souza, and A. L. Lock. 2021a. Nutrient digestibility and production responses of lactating dairy cows when saturated free fatty acid supplements are included in diets: A meta-analysis. J. Dairy Sci. 104:12628-12646. https://doi.org/ 10.3168/jds.2021-20699.

dos Santos Neto, J. M., J. de Souza, and A. L. Lock. 2021b. Effects of calcium salts of palm fatty acids on nutrient digestibility and production responses of lactating dairy cows: A meta-analysis and meta-regression. J. Dairy Sci. 104:9752-9768. https://doi.org/10 $.3168 /$ jds.2020-19936.

Drackley, J. K. 2000. Lipid metabolism. Pages 97-119 in Farm Animal Metabolism and Nutrition. J. P. F. D'Mello, ed. CABI Publishing.

Drackley, J. K., T. R. Overton, G. Ortiz-Gonzalez, A. D. Beaulieu, D. M. Barbano, J. M. Lynch, and E. G. Perkins. 2007. Responses to increasing amounts of high-oleic sunflower fatty acids infused into the abomasum of lactating dairy cows. J. Dairy Sci. 90:5165-5175. https://doi.org/10.3168/jds.2007-0122.

Erickson, D. R., W. L. Dunkley, and M. Ronning. 1963. Effect of intravenously injected tocopherol on oxidized flavor in milk. J. Dairy Sci. 46:911-915. https://doi.org/10.3168/jds.S0022-0302(63)89178 $-\mathrm{X}$.

Fontoura, A. B. P., J. E. Rico, A. N. Davis, W. A. Myers, B. N. Tate, R. Gervais, and J. W. McFadden. 2021. Effects of dietary deoiled soy lecithin supplementation on milk production and fatty acid digestibility in Holstein dairy cows. J. Dairy Sci. 104:1823-1837. https://doi.org/10.3168/jds.2020-18797.

Freeman, C. P. 1969. Properties of fatty acids in dispersions of emulsified lipid and bile salt and the significance of these properties in fat absorption in the pig and the sheep. Br. J. Nutr. 23:249-263. https://doi.org/10.1079/BJN19690032.

Glasser, F., A. Ferlay, M. Doreau, P. Schmidely, D. Sauvant, and Y. Chilliard. 2008. Long-chain fatty acid metabolism in dairy cows: A meta-analysis of milk fatty acid yield in relation to duodenal flows and de novo synthesis. J. Dairy Sci. 91:2771-2785. https://doi.org/ 10.3168/jds.2007-0383.

Goering, H. K., and P. J. Van Soest. 1970. Forage Fiber Analysis (Apparatus, Reagents, Procedures, and Some Applications). Agricultural Handbook no. 379. USDA Agricultural Research Service.
Goto, M., H. Bae, S. S. Lee, M. S. Yahaya, S. Karita, K. Wanjae, and K. J. Cheng. 2003. Effects of surfactant Tween 80 on forage degradability and microbial growth on the in vitro rumen mixed and pure cultures. Asian-Australas. J. Anim. Sci. 16:672-676. https:// doi.org/10.5713/ajas.2003.672.

Harvatine, K. J., and M. S. Allen. 2006. Effects of fatty acid supplements on milk yield and energy balance of lactating dairy cows. J. Dairy Sci. 89:1081-1091. https://doi.org/10.3168/jds.S0022 -0302(06)72176-2.

He, M., K. L. Perfield, H. B. Green, and L. E. Armentano. 2012. Effect of dietary fat blend enriched in oleic or linoleic acid and monensin supplementation on dairy cattle performance, milk fatty acid profiles, and milk fat depression. J. Dairy Sci. 95:1447-1461. https:// doi.org/10.3168/jds.2011-4635.

Hofmann, A. F. 1963. The function of bile salts in fat absorption. Biochem. J. 89:57-68.

Jenkins, K. J., and D. B. Emmons. 1984. Tolerance of calves to fat peroxides in milk replacer. J. Dairy Sci. 67:592-597. https://doi .org/10.3168/jds.S0022-0302(84)81343-0.

Jenkins, T. C., and N. Fotouhi. 1990. Effects of lecithin and corn oil on site of digestion, ruminal fermentation and microbial protein synthesis in sheep. J. Anim. Sci. 68:460-466. https://doi.org/10 $.2527 / 1990.682460 \mathrm{x}$

Jensen, R. G. 2002. The composition of bovine milk lipids: January 1995 to December 2000. J. Dairy Sci. 85:295-350. https://doi.org/ 10.3168/jds.S0022-0302(02)74079-4.

Kamande, G. M., J. Baah, K.-J. Cheng, T. A. McAllister, and J. A. Shelford. 2000. Effects of Tween 60 and Tween 80 on protease activity, thiol group reactivity, protein adsorption, and cellulose degradation by rumen microbial enzymes. J. Dairy Sci. 83:536-542. https://doi.org/10.3168/jds.S0022-0302(00)74913-7.

Kaur, G., and S. K. Mehta. 2017. Developments of polysorbate (Tween) based microemulsions: Preclinical drug delivery, toxicity and antimicrobial applications. Int. J. Pharm. 529:134-160. https: //doi.org/10.1016/j.ijpharm.2017.06.059.

Kinsella, J. E., and M. Gross. 1973. Palmitic acid and initiation of mammary glyceride synthesis via phosphatidic acid. Biochim. Biophys. Acta Lipids Lipid Metab. 316:109-113. https://doi.org/10 .1016/0005-2760(73)90172-0.

Kralova, I., and J. Sjöblom. 2009. Surfactants used in food industry: A review. J. Dispers. Sci. Technol. 30:1363-1383. https://doi.org/10 $.1080 / 01932690902735561$.

Lee, C., D. L. Morris, J. Copelin, J. Hettick, and I. Kwon. 2019. Effects of lysophospholipids on short-term production, nitrogen utilization, and rumen fermentation and bacterial population in lactating dairy cows. J. Dairy Sci. 102:3110-3120. https://doi.org/ $10.3168 /$ jds.2018-15777.

Lee, S. S., and J. K. Ha. 2003. Influences of surfactant Tween 80 on the gas production, cellulose digestion and enzyme activities by mixed rumen microorganisms. Asian-Australas. J. Anim. Sci. 16:1151-1157. https://doi.org/10.5713/ajas.2003.1151.

Lock, A. L., C. L. Preseault, J. E. Rico, K. E. DeLand, and M. S. Allen. 2013. Feeding a C16:0-enriched fat supplement increased the yield of milk fat and improved conversion of feed to milk. J. Dairy Sci. 96:6650-6659. https://doi.org/10.3168/jds.2013-6892.

Lock, A. L., C. Tyburczy, D. A. Dwyer, K. J. Harvatine, F. Destaillats, Z. Mouloungui, L. Candy, and D. E. Bauman. 2007. Trans-10 octadecenoic acid does not reduce milk fat synthesis in dairy cows. J. Nutr. 137:71-76. https://doi.org/10.1093/jn/137.1.71.

Maldonado-Valderrama, J., P. Wilde, A. MacIerzanka, and A. MacKie. 2011. The role of bile salts in digestion. Adv. Colloid Interface Sci. 165:36-46.

Månsson, H. L. 2008. Fatty acids in bovine milk fat. Food Nutr. Res. 52:1821. https://doi.org/10.3402/fnr.v52i0.1821.

Noble, R. C. 1978. Digestion, absorption and transport of lipids in ruminant animals. Prog. Lipid Res. 17:55-91. https://doi.org/10 .1016/0079-6832(78)90005-8.

NRC. 2001. Nutrient Requirements of Dairy Cattle. 7th ed. National Academies Press.

Ockner, R. K., J. P. Pittman, and J. L. Yager. 1972. Differences in the intestinal absorption of saturated and unsaturated long chain fat- 
ty acids. Gastroenterology 62:981-992. https://doi.org/10.1016/ S0016-5085(72)80115-X.

Piantoni, P., A. L. Lock, and M. S. Allen. 2013. Palmitic acid increased yields of milk and milk fat and nutrient digestibility across production level of lactating cows. J. Dairy Sci. 96:7143-7154. https://doi .org $/ 10.3168 /$ jds.2013-6680.

Piantoni, P., A. L. Lock, and M. S. Allen. 2015. Milk production responses to dietary stearic acid vary by production level in dairy cattle. J. Dairy Sci. 98:1938-1949. https://doi.org/10.3168/jds .2014-8634

Prom, C. M., and A. L. Lock. 2021. Replacing stearic acid with oleic acid in supplemental fat blends improves fatty acid digestibility of lactating dairy cows. J. Dairy Sci. 104:9956-9966. https://doi.org/ 10.3168/jds.2020-19985.

Prom, C. M., J. M. dos Santos Neto, J. R. Newbold, and A. L. Lock. 2021. Abomasal infusion of oleic acid increases fatty acid digestibility and plasma insulin of lactating dairy cows. J. Dairy Sci. 104:12616-12627. https://doi.org/10.3168/jds.2021-20954.

Relling, A. E., and C. K. Reynolds. 2007. Feeding rumen-inert fats differing in their degree of saturation decreases intake and increases plasma concentrations of gut peptides in lactating dairy cows. J. Dairy Sci. 90:1506-1515. https://doi.org/10.3168/jds.S0022 -0302(07)71636-3.

Rico, J. E., J. de Souza, M. S. Allen, and A. L. Lock. 2017. Nutrient digestibility and milk production responses to increasing levels of palmitic acid supplementation vary in cows receiving diets with or without whole cottonseed. J. Anim. Sci. 95:436-446. https://doi .org/10.2527/jas.2016.1089.

Scrimgeour, C. M., and J. L. Harwood. 2007. Fatty acid and lipid structure. Pages 15-50 in The Lipid Handbook. F. D. Gunstone, J. L. Harwood, J. L. Harwood, ed. CRC Press.

Shain, D. H., M. H. Sindt, R. J. Grant, T. J. Klopfenstein, and R. A. Stock. 1993. Effect of soybean hull:soy lecithin:soapstock mixture on ruminal digestion and performance of growing beef calves and lactating dairy cattle. J. Anim. Sci. 71:1266-1275. https://doi.org/ $10.2527 / 1993.7151266 \mathrm{x}$.

Shepardson, R. P., and K. J. Harvatine. 2021. Effects of fat supplements containing different levels of palmitic and stearic acid on milk production and fatty acid digestibility in lactating dairy cows. J. Dairy Sci. 104:7682-7695. https://doi.org/10.3168/jds .2020-19665.

Shreve, B., N. Thiex, and M. Wolf. 2006. NFTA Method 2.1.4-Dry matter by oven drying for $3 \mathrm{hr}$ at 105C. National Forage Testing Association.

Smith, A., and A. K. Lough. 1976. Micellar solubilization of fatty acids in aqueous media containing bile salts and phospholipids. Br. J. Nutr. 35:77-87. https://doi.org/10.1079/BJN19760011.

Tyburczy, C., A. L. Lock, D. A. Dwyer, F. Destaillats, Z. Mouloungui, L. Candy, and D. E. Bauman. 2008. Uptake and utilization of trans octadecenoic acids in lactating dairy cows. J. Dairy Sci. 91:3850-3861. https://doi.org/10.3168/jds.2007-0893.

Tyrrell, H. F., and J. T. Reid. 1965. Prediction of the energy value of cow's milk. J. Dairy Sci. 48:1215-1223. https://doi.org/10.3168/ jds.S0022-0302(65)88430-2.

Tzompa-Sosa, D. A., G. A. van Aken, A. C. M. van Hooijdonk, and H. J. F. van Valenberg. 2014. Influence of C16:0 and long-chain saturated fatty acids on normal variation of bovine milk fat triacylglycerol structure. J. Dairy Sci. 97:4542-4551. https://doi.org/ 10.3168/jds.2014-7937.

Upadhaya, S. D., J. W. Park, J. H. Park, and I. H. Kim. 2017. Efficacy of 1,3-diacylglycerol as a fat emulsifier in low-density diet for broilers. Poult. Sci. 96:1672-1678. https://doi.org/10.3382/ps/pew425.

Western, M. M., J. de Souza, and A. L. Lock. 2020a. Effects of commercially available palmitic and stearic acid supplements on nutrient digestibility and production responses of lactating dairy cows. J. Dairy Sci. 103:5131-5142. https://doi.org/10.3168/jds.2019 $-17242$.

Western, M. M., J. de Souza, and A. L. Lock. 2020b. Milk production responses to altering the dietary ratio of palmitic and oleic acids varies with production level in dairy cows. J. Dairy Sci. 103:1147211482. https://doi.org/10.3168/jds.2020-18936.

Westreicher-Kristen, E., and A. Susenbeth. 2017. Technical note: An improved tool to insert lines for abomasal infusion in rumen cannulated cattle. J. Dairy Sci. 100:1951-1954. https://doi.org/10 $.3168 /$ jds.2016-12150.

Wildman, E. E., G. M. Jones, P. E. Wagner, R. L. Boman, H. F. Troutt Jr., and T. N. Lesch. 1982. A dairy cow body condition scoring system and its relationship to selected production characteristics. J. Dairy Sci. 65:495-501. https://doi.org/10.3168/jds .S0022-0302(82)82223-6.

Zhao, P. Y., H. L. Li, M. M. Hossain, and I. H. Kim. 2015. Effect of emulsifier (lysophospholipids) on growth performance, nutrient digestibility and blood profile in weanling pigs. Anim. Feed Sci. Technol. 207:190-195. https://doi.org/10.1016/j.anifeedsci.2015 .06 .007 .

Zhao, P. Y., Z. F. Zhang, R. X. Lan, W. C. Liu, and I. H. Kim. 2017. Effect of lysophospholipids in diets differing in fat contents on growth performance, nutrient digestibility, milk composition and litter performance of lactating sows. Animal 11:984-990. https:// doi.org/10.1017/S1751731116002238.

\section{ORCIDS}

Crystal M. Prom @ ittps://orcid.org/0000-0003-0921-5529

José M. dos Santos Neto — https://orcid.org/0000-0002-5335-8933

Adam L. Lock @ https://orcid.org/0000-0002-9282-399X 